\title{
TRABALHADORES "DESOSSADORES" DE CARNE BOVINA PROCEDENTES DE NOVA ANDRADINA (MATO GROSSO DO SUL, BRASIL) ATUANDO PROFISSIONALMENTE NA CIDADE DE CLONES, NA IRLANDA.
}

\author{
Alexandre Honig Gonçalves ${ }^{1}$ \\ Rodrigo Vilas Boas de Souza ${ }^{2}$
}

\begin{abstract}
RESUMO: Migração é um exercício inerente Homem e cada vez mais tem havido migrações determinadas pela busca de melhores condições de vida por meio do trabalho decente. Trabalhadores abandonam seus países de origem, a fim de se fixarem em países mais desenvolvidos. Neste quadro é possível perceber a conformação e uso ativo de redes de trabalhadores que, prosseguem conectados via internet, compartilhando informações e prosseguindo rumo a uma vida de labor, distantes de suas famílias e países de origem a partir das orientações recebidas por meio destas redes. Assim sendo, o objetivo deste texto é descrever e analisar, a situação dos trabalhadores "desossadores" de carne bovina procedentes de Nova Andradina, no Mato Grosso do Sul, que atuam na Europa, especificamente na Irlanda, cidade de Clones, no condado de Monaghan.
\end{abstract}

Palavras-chave: Migração Internacional, Trabalho, Redes.

\section{BEEF PLANT WORKERS FROM NOVA ANDRADINA (MATO GROSSO DO SUL STATE, BRAZIL) WORKING PROFESSIONALLY IN THE CITY OF CLONES (IRELAND)}

Abstract: Migration is an inherent exercise about humanity. Actualy have been migrations determined by the search for better living conditions through decent work. Workers leave their countries of origin in order to settle in more developed countries. In this context, it's possible to perceive the conformation and active use of networks of workers, who continue to be connected via the internet, sharing information and continuing towards a life of work, distant from their families and countries of origin from the guidelines received through these networks. Therefore, the aim of this text is describe and analyze the situation of beef plant workers from Nova Andradina, in Mato Grosso do Sul stat (Brazil) e, who work in Europe, specifically in Ireland, city of Clones, in the county of Monaghan .

Keywords: International Migration, Work, Networks.

\footnotetext{
${ }^{1}$ Doutor em Geografia pela Universidade Federal da Grande Dourados (UFGD). Email: alexandrehgoncalves@ gmail.com

${ }^{2}$ Mestre em Geografia pela Universidade Estadual de Maringá (UEM). Email: rodrigo.souza@unicesumar.edu.br
} 


\section{INTRODUÇÃO}

A migração é um exercício inerente e recorrente à sobrevivência e ao progresso do Homem no planeta Terra ao longo do tempo histórico. Sozinho, em pequenos grupos ou, mesmo em comunidades inteiras, este se desloca em busca de condições de subsistência, para fugir de conflitos, guerras, violência, perseguições religiosas/étnicas ou ainda, para galgar melhores oportunidades e progresso econômico para si, sua família ou comunidade (GONÇALVES; JOHNSON, 2016a).

Atualmente, há cerca de 250 milhões de pessoas na condição de migrantes internacionais ao redor do mundo, sendo que destes, mais de 68 milhões encontram-se em situação de deslocamento forçado (ACNUR, 2019, p. 01).

A crescente facilidade relativa à mobilidade internacional por meio do acesso a informações relevantes e, sobretudo a uma rede logística global razoavelmente integrada e dinâmica, associada concomitantemente a possibilidade de verificação de assimetrias nacionais com relação às condições de vida em diferentes países, leva trabalhadores e trabalhadoras a se deslocarem mundo afora em busca de melhores posições de emprego e renda (GONÇALVES; JOHNSON, 2016b; GONÇALVES; JESUS, 2016).

Nesse sentido, cada vez mais têm havido migrações determinadas pela busca de melhores condições de vida por meio do trabalho decente. Desta feita, trabalhadores abandonam seus países de origem, normalmente sociedades em processo de desenvolvimento econômico incipiente ou precário, a fim de se fixarem em "países mais desenvolvidos" economicamente, socialmente, politicamente e culturalmente (MATIAS, 2014, p. 34).

Há de se destacar que a própria globalização traz consigo alterações aos fluxos migratórios contemporâneos, em que trabalhadores advindos de países desenvolvidos também têm prosseguido com destino aos países em fase de desenvolvimento, a fim de se aproveitarem das oportunidades vinculadas ao processo de crescimento econômico decorrente destes países. Paralelamente, há ainda empresas privadas do hemisfério Norte, que recrutam trabalhadores do Sul global para instrumentalizar e operacionalizar suas ações em seus países de origem (JESUS; GONÇALVES, 2017, p. 218).

Por conseguinte, é pertinente destacar que os movimentos migratórios são resultado das reestruturações espaciais do próprio capital. E, neste sentido, seus fluxos estão aglomerando, em escalas sem precedentes na história, as forças de trabalho em configurações concorrenciais extremamente nocivas a concepção de classe e solidariedade, fragmentando-as, ao mesmo tempo em que a aloca em um determinado território. Logo, a compreensão espaço temporal do capital e do trabalho produzem uma gama de tensões e respostas políticas que variam em espectros extremos (HARVEY, 2018, p. 185).

Paralela a toda argumentação supracitada é possível perceber a conformação e uso ativo de redes de trabalhadores que, prosseguem conectados via internet e suas redes sociais específicas (Facebook, Instagran, Youtube, WhatsApp, etc.), compartilhando informações e prosseguindo rumo a uma vida de labor, distantes de suas famílias e países de origem a partir das orientações recebidas por meio destas redes (SAQUET; MONDARDO, 2008, p. 5).

Frente ao panorama descrito, o objetivo deste texto é descrever e analisar, a situação dos trabalhadores "desossadores" de carne bovina procedentes de Nova 
Andradina, no Mato Grosso do Sul, que atuam na Europa, especificamente na Irlanda, cidade de Clones, no condado de Monaghan.

Para tanto, edificamos uma reflexão crítica lastreada em uma análise multidimensional para que possamos compreender os fenômenos migratórios contemporâneos que são motivados pela busca de trabalho, intermediados pelas interações em redes, por meio deste estudo de caso.

\section{MÉTODO DE PESQUISA}

A priori, é pertinente destacar que frente ao característico e complexo cenário em que se insere o fenômeno estudado e, a fim de dar conta de responder plenamente ao objetivo proposto, decidiu-se por uma pesquisa de caráter exploratório e descritivo que se ampare em diversas técnicas e procedimentos para coleta e análise de dados.

Com relação à edificação do referencial teórico-metodológico deste estudo, optou-se pelo levantamento de dados secundários. Em artigos científicos, teses de Doutorado, dissertações de Mestrado e, também em periódicos não científicos de circulação restrita e local que versam sobre o assunto e, em documentos históricos. Estes materiais foram localizados por meio do acesso a repositórios de Universidades nacionais e internacionais, bases de dados on-line (Periódicos CAPES), prospecção na biblioteca pública e, também, no museu da cidade de Nova Andradina, no Mato Grosso do Sul (Brasil).

Em fase posterior, desenvolveu-se o trabalho de campo, utilizando-se de questionários semiestruturados para coleta de dados primários, por meio de entrevistas em profundidade. Esta fase deu-se em duas ocasiões: A) local, em que foram realizadas três entrevistas: A1) com o presidente do Sindicato dos Trabalhadores das Indústrias de Alimentação de Nova Andradina e Região (STIANA); A2) com um ex-funcionário de frigorífico; A3) com dois pecuaristas de Nova Andradina; B) internacional. Nesta fase, optamos por entrevistar os trabalhadores "desossadores" selecionados por meio de chamadas com vídeo, via WhatsApp. Foram seis os entrevistados por este meio tecnológico. Todos residentes na cidade de Clones, no condado de Monaghan, na Irlanda. Para seleção destes sujeitos sociais que perfazem o fenômeno estudado, buscamos construir uma narrativa por meio da amostragem teórica.

As entrevistas foram registradas por meio de recursos de áudio gravação (aparelho de telefone celular: Samsung A8). Somados, há 75 minutos de áudio salvos. As entrevistas ocorreram entre junho e outubro de 2019.

Com a sinergia destes elementos houve a conformação de um estudo de caso em que se buscou compreender adequadamente o fenômeno social, frente a importantes condicionantes contextuais do cenário local, nacional e internacional (FACHIN, 2006, p. 56).

A narrativa discursiva estabelecida por meio das entrevistas coletadas edifica um texto dissertativo, composto por meio da transcriação. Com este método buscamos estabelecer novas aparências estéticas à transcrição, mantendo inalteradas as qualidades, objetivos e significados propostos pelo autor original. Entretanto, ajustando o material a uma realidade utilitária e estética específicas (TOSIN, 2011, p. 03).

O processo de análise dos dados coletados apoia-se no método dedutivo, que é um procedimento lógico de raciocínio que, a partir da análise de dados genéricos, 
se segue ao conhecimento particular e específico acerca do objeto de estudo em questão (FACHIN, 2006, p. 33).

\section{"DESOSSADORES" DE CARNE BOVINA PROCEDENTES DE NOVA ANDRADINA (MATO GROSSO DO SUL, BRASIL) TRABALHANDO NA CIDADE DE CLONES, NA IRLANDA.}

Nesta seção do artigo procuramos elaborar uma narrativa que aborde os seguintes temas relativos à pesquisa, ao fenômeno e ao objeto de estudo: I) condicionantes históricos; II) o processo de migração internacional; III) a situação dos trabalhadores "desossadores" de carne bovina de Nova Andradina (MS) que trabalham na cidade de Clones, na Irlanda.

Com relação aos condicionantes geográficos e históricos (ponto I), podemos indicar que Nova Andradina é um município do estado de Mato Grosso do Sul, situado na região Centro-Oeste do Brasil. Encontra-se na confluência logística entre os estados de Mato Grosso do Sul, São Paulo e Paraná. Tal qual indicado na Figura 01 .

Figura 1. Mapa do município de Nova Andradina no âmbito de Brasil e estado de Mato Grosso do Sul

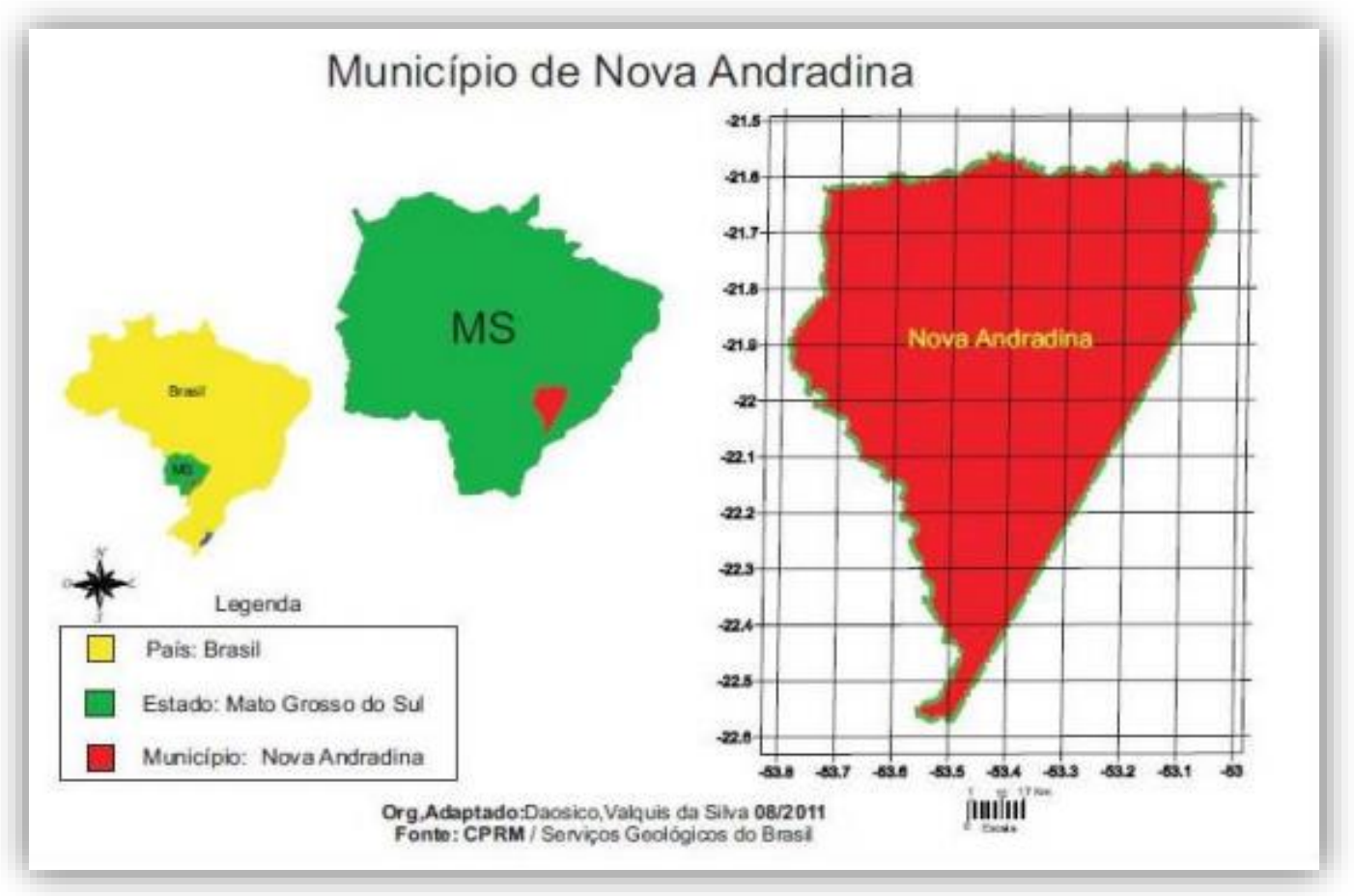

Fonte: Moreira e Schlindwein (2015)

Cabe salientar que esta configuração do território em função de seu uso econômico é resultado de ações antrópicas históricas que seguem uma lógica de exploração dos recursos naturais de modo intensivo. Primeiro, houve um ciclo madeireiro, em que se desmatou a vegetação natural, depois, a inclusão de pastagens para criação de gado bovino e agricultura extensiva (GONÇALVES; GONÇALVES, 2013).

Contemporaneamente o município possui uma área territorial de 4.77 .002 $\mathrm{Km}^{2}$, conta com uma população estimada de 54.374 habitantes (em 2019), maior 
que a relatada no senso de 2010 , que era de 45.585 habitantes. É o $8^{\circ}$ município mais populoso de Mato Grosso do Sul. O IDH (2010) é de 0,721 (2010), sendo considerado Alto (IBGE, 2019; PNUD, 2019).

Com relação à economia, possui um PIB per capita de $\mathrm{R} \$ 35.268,78$ ao ano. Todavia, o salário médio mensal dos trabalhadores formais (em 2017) era de 2,1 salários mínimos e o percentual da população com rendimento nominal mensal per capita de até $1 / 2$ salário mínimo era de 31,6\%. A população economicamente ativa ocupada é de $72,6 \%$ e a desocupada de 21,8\% (IBGE, 2019; PNUD, 2019). Portanto, há um cenário de concentração de renda nesta sociedade e neste mercado.

Este quadro coloca Nova Andradina como sendo a $9^{a}$ economia do estado de Mato Grosso do Sul; 445 ${ }^{a}$ no Brasil. Suas principais atividades econômicas estão vinculadas diretamente com a agropecuária, indústria, serviços e administração pública (IBGE, 2019). Com relação à agropecuária, Nova Andradina é o 13ำ município em faturamento no estado de Mato Grosso do Sul decorrente da atividade; $83^{\circ}$ no Brasil. Com relação à indústria, é o $7^{\circ}$ em faturamento no estado de Mato Grosso do Sul e o 504ํㅜㄹocado no ranking do Brasil (IBGE, 2019).

Paralelamente, do ponto de vista histórico, é importante destacar que a marcha de ocupação da região fora fomentada pelo próprio governo do Presidente Getulio Vargas e, em igual medida, pelo regime militar do Brasil, por meio de suas políticas de expansão da fronteira agrícola brasileira rumo ao Centro-Oeste do País (FARIA, et. all, 2010). Mas, também é pertinente salientar que, preteritamente, houveram iniciativas para a ocupação deste espaço geográfico ainda no período colonial, por intermédio das campanhas de exploração do território nacional por parte dos Bandeirantes paulistas e, mesmo em função da Guerra do Paraguai (GOES FILHO, 2015, p. 113 e 287; MOTA, 1995, p. 251).

Com relação específica constituição do município, cabe descrever que as terras que hoje conformam Nova Andradina foram sendo adquiridas e conquistadas no ainda estado do Mato Grosso, no final da década de 1930. A divisão do estado (MT e MS) ocorreu somente em 1977 (BRASIL, 1977). Assim sendo, vale citar que o município foi fundado em 20 de Dezembro de 1958 e instalado oficialmente no dia 30 de Abril de 1959. O fundador deste município foi Antônio Joaquim de Moura Andrade, o mesmo colonizador de Andradina, no interior do estado de São Paulo (IBGE, 2019).

Inicialmente a composição gentílica do município deu-se em função da atração de migrantes brasileiros advindos dos estados de São Paulo, Paraná, Minas Gerais e, em grande número de pessoas saídas dos estados da região nordeste do Brasil (IBGE, 2019). Adicionalmente, no campo das migrações internacionais, é possível indicar que grupos compostos por paraguaios, japoneses, franceses e tchecoslovacos também fizeram parte da história de colonização e formação da sociedade nova-andradinense (PELLICCIARI NETTO, 2004, s.p.; NANTES, 2007, p. 163; SANTOS, 2010, p. 24).

A composição dessa colonização deu-se de modo bastante dinâmico e intenso, mas, em igual medida bruta e violenta. Comunidades indígenas originárias foram deslocadas (etnia Ofaié-Xavante) (GONÇALVES; CARVALHO, 2005, p. 03; DUTRA, 2011, p. 148; DUTRA, 1991, p. 33), posseiros e grileiros foram retirados à força e, as relações de trabalho entre os representantes da empresa colonizadora e os empregados eram permeadas por coerção (ZOTI, 2017, p.138).

Paralelamente, outro elemento histórico que precede de modo importante à composição atual do perfil produtivo e socioeconômico de Nova Andradina, foram as 
charqueadas. Chamaram-se charqueadas os estabelecimentos que salgavam a carne e os couros bovinos para comercializá-los. $O$ objetivo destes empreendimentos no sul do Estado de Mato Grosso era fornecer estes produtos ao mercado platino e, mesmo ao mundial (QUEIROZ, 2010, p. 13). A produção de charque, os couros e outros derivados do boi, no período posterior à guerra contra os paraguaios, no final do Século XIX, fomentou a economia pecuária na região. Com relação ao consumo nacional, os bois e o charque produzidos nesta região eram destinados ao consumo interno das fazendas e cidades mato-grossenses e encaminhados à orla marítima atlântica do Brasil, para serem comercializado e consumido nas grandes cidades, em larga medida, seguiam aos mercados interiores dos estados de Minas Gerais e São Paulo, atravessando sertões em comitivas rumo aos mercados consumidores (CORRÊA; CORRÊA, 2010, p. 45).

Nesse sentido, o desenvolvimento da economia pecuária no Mato Grosso e no sul do estado especificamente, foi impulsionado por conta das terras abundantes, força de trabalho e matérias-primas disponíveis e baratas, desde as últimas décadas do século XIX até por volta dos anos 1920/1930. Contudo, nesta mesma época, frigoríficos modernos foram sendo instalados na região platina, trazendo a decadência ao ciclo econômico das charqueadas situadas na Argentina, no Uruguai e, especificamente no Brasil, neste caso, em Mato Grosso e no sul do estado.

Já a partir de 1912 também foram sendo instalados os primeiros frigoríficos no Brasil, a princípio situados no eixo São Paulo/Rio de Janeiro/Minas Gerais (CORRÊA; CORRÊA, 2010, p. 55). Assim sendo, após as décadas de 1920/1930, a produção do charque viveu um lento processo de declínio, em um período histórico de retração dos mercados internacionais consumidores (pós-Primeira Guerra Mundial). Essa situação coincidiu com a desarticulação econômica de grupos estrangeiros no sul de Mato Grosso, que produziam e exportavam charque em grande escala. Nesses termos, a economia pecuária atrelada ao charque deixou de merecer a atenção de investidores que pudessem manter a atividade. Desta feita, as aplicações financeiras migraram para o incremento dos frigoríficos (CORRÊA; CORRÊA, 2010, p. 67; QUEIROZ, 2008, p. 10).

Ao longo deste período histórico a atividade econômica mais importante na região de Nova Andradina permaneceu sendo a agropecuária. Todavia, o abate de bovinos ocorria em açougues e matadouros locais, mas, a produção era destinada somente ao consumo no município e região. Os grandes rebanhos criados na região eram direcionados, por meio de caminhões boiadeiros à frigoríficos do interior dos estados de São Paulo e Paraná, para que os bovinos pudessem ser abatidos, processados e, posteriormente, encaminhados aos grandes centros urbanos e mercados consumidores do país.

O primeiro empreendimento relacionado à construção e operação de um frigorífico moderno no município deu-se por iniciativa de Marcus Vinicius Godoy Garcia. O FRIGNAN (Frigorífico de Nova Andradina), que foi inaugurado já no final da década de 1980, com capacidade de abater e resfriar cerca de 200 animais por dia, com a finalidade de atender o mercado regional e nacional. Ao iniciar suas atividades o frigorífico já contava com os certificados de inspeção sanitária em todos os níveis (municipal, estadual e federal), o que significa que já estava apto a desenvolver suas atividades dentro dos padrões de segurança, sanidade e qualidade impostos pelo Estado. A planta industrial deste empreendimento foi arrendada e, posteriormente vendida a outro grupo privado nos anos 2000, contemporaneamente está em atividade e é denominado NATURAFRIG. 
No processo de abertura e operação do FRIGNAN, se inicia a conformação do fenômeno social a que nos propomos a estudar neste artigo. Para abater e processar as matérias-primas seria necessária uma mão de obra qualificada para esta função e, como na época não havia trabalhadores com este perfil no município ou região, foram contratados trabalhadores "desossadores" provenientes da cidade de Andradina/SP, que atuavam em uma das empresas do grupo Moura Andrade, o frigorífico MOURAN. De tal modo que se dá a primeira remessa de migrantes "desossadores" com destino à Nova Andradina e, assim sendo estes trabalhadores passaram a figurar no cotidiano da cidade.

Por "desossador" ou, "açougueiro desossador" ou, "magarefe" ou, "faqueiro" devemos compreender que são os trabalhadores da produção de bens industriais, da fabricação de alimentos, trabalhadores artesanais na agroindústria, em que as funções são abater os animais, preparar carnes para comercialização, preparar carcaças de animais (aves, bovinos, caprinos, ovinos e suínos), tratar vísceras e acondicionar carnes, etc. Estes profissionais devem atuar em conformidade com as normas e procedimentos técnicos e de qualidade, segurança, higiene, saúde e preservação ambiental. (BRASIL, 2019).

Adiante neste processo histórico e, frente às potencialidades territoriais e produtivas do município de Nova Andradina, nos idos dos anos 1990, Antônio Russo inaugura o frigorífico Independência. Nesta época, esta planta de abate, refrigeração e processamento de carne bovina fora edificada como sendo a mais bem aparelhada e moderna instalação do setor frigorífico de Mato Grosso do Sul e do Brasil. Apta a abater e refrigerar, inicialmente, cerca de 400 animais por dia, com a finalidade de atender ao mercado nacional e internacional. Ao longo do tempo a capacidade instalada para abate, refrigeração e processamento foram sendo ampliados para 700 animais por dia e, finalmente, 1.200 animais por dia já no início dos anos 2000 (REV. HOJE, 2002, p. 20).

Ao iniciar suas atividades este frigorífico já contava com os certificados de inspeção sanitária em todos os níveis (municipal, estadual e federal), o que significa que já estava apto a desenvolver suas atividades dentro dos padrões de segurança, sanidade e qualidade impostos pelo Estado. Inclusive, esta unidade foi concebida com a proposta de ser o modelo para as demais plantas frigoríficas do grupo Independência que estavam em operação ou, seriam construídas no estado, no Brasil e no exterior.

Neste complexo agroindustrial do grupo Independência no município de Nova Andradina, anexos ao frigorífico foram instalados um curtume e uma fábrica de sabão, a fim de processar, também, os subprodutos do abate dos bovinos. Além de um centro logístico próprio para atender as demandas desta unidade produtiva e das demais plantas agroindustriais do grupo que se instaram no estado.

Com esta configuração, este complexo agroindustrial do grupo Independência em Nova Andradina foi responsável pela geração de 1.388 empregos diretos no município, fora os indiretos ao longo das cadeias produtivas associadas diretamente as suas operações na região. Em conjunto com as outras unidades do grupo no estado, nos municípios de Campo Grande (400 empregos diretos) e de Anastácio (800 empregos diretos), no início dos anos 2000 este foi considerado grupo privado que mais empregava mão de obra em Mato Grosso do Sul (REV. HOJE, 2002, p. 20).

Com relação à produção e processamento de carne bovina nesta unidade, $76 \%$ estava destinada a exportação. O frigorífico Independência destinava seus produtos a mais de 40 países, sendo os mercados norte-americano, europeu, 
asiático e russo seus destaques. Esta unidade também processava seus produtos conforme as indicações religiosas e culturais dos povos muçulmanos (Halal) e judeus (Kosher), a fim de atender plenamente estes mercados consumidores (PELLICCIARI NETTO, 2004, s.p.).

Neste sentido, esta unidade agroindustrial ainda contava com uma pista de pouso para aviões asfaltada, sinalizada, homologada e operante, com a finalidade de atender os executivos e técnicos da empresa, já que esta era a unidade modelo e de referência nas operações do grupo. Mas, sobretudo, esta pista fora concebida para receber as visitas dos compradores, incluindo os internacionais.

Com esta situação, o frigorífico e os funcionário do Independência de Nova Andradina passaram a estreitar os laços institucionais do grupo com iniciativas internacionais, fato que possibilitou o intercâmbio dos trabalhadores "desossadores" do município com outros frigoríficos mundo a fora e, a partir dos contatos dos compradores estrangeiros e de instituições parceiras do grupo no exterior, se formou uma rede e, iniciou-se o processo de migração destes trabalhadores para vários países, com destaque para Austrália e Irlanda.

Para a Austrália por iniciativa do próprio grupo Independência que adquiriu plantas frigoríficas neste país, com a finalidade de explorar seu mercado local e, em igual medida, para estar mais próximo geograficamente dos mercados asiáticos (ORTELAN, 2016, p. 57). Para tanto, recrutou em suas unidades brasileiras e, principalmente, em Nova Andradina e, enviou a este país uma turma de "desossadores" para que estes pudessem trabalhar, treinar e formar novas equipes de funcionários.

Paralelamente, com destino à Irlanda, o fluxo migratório destes trabalhadores é decorrente da contratação de "desossadores" do estado de Goiás para atuar naquele país, ainda na década de 1990 (SILVA, 2016, p. 55). Desta forma, por meio das redes de informações e comunicação dos sindicatos de classe destes trabalhadores, o destino ficou conhecido e, neste sentido, os "desossadores" provenientes de Nova Andradina, também alcançaram esta paragem.

Mas, mesmo frente ao apogeu e glória do grupo Independência ao longo dos anos no Brasil e no mundo, com a crise financeira global de 2008 e seus desdobramentos negativos sobre vários setores produtivos, inclusive o frigorífico, a empresa não sobreviveu ao processo de reorganização do setor frigorífico e entrou em falência em 2009 (GOLANI; MOITA, 2010, p. 02; MONTEIRO, 2012, p. 134), sua recuperação judicial não conseguiu restabelecer suas operações adequadamente e, em 2012 o grupo JBS adquiriu e incorporou definitivamente as operações do grupo Independência, que deixou de existir (BEEFPOINT, 2012). A unidade agroindustrial do município de Nova Andradina encerrou suas operações em 2009 e, retomou suas operações somente em dezembro de 2012, já sob a propriedade do grupo JBS (BEEFPOINT, 2012).

Com mais esta aquisição o JBS se tornou o maior grupo brasileiro com atuação transnacional do setor de processamento de carnes do mundo, com acesso a $100 \%$ dos mercados consumidores do mundo e capacidade de produção e processamento nos quatro principais países produtores de carne bovina do mundo (Brasil, Argentina, Estados Unidos e Austrália). Desta forma o JBS tornou-se líder em exportação neste setor e, a primeira empresa no mundo em capacidade de abate (47,1 mil animais por dia) (FOOD INGREDIENTS BRASIL, 2009, p. 36; AOUN; VERDI, 2010, p. 106; JBS, 2018, p. 10).

Adiante, com relação específica ao processo de migração internacional destes trabalhadores (ponto II), com destino à Irlanda, é pertinente destacar algumas 
etapas. A abertura e o direcionamento das vagas se dão em função da demanda específica do contratante, com a anuência de seu Estado/governo (critical skills ocucupations list ou, ineligible list of occupations for employment permits), em que se determinam a classe ou categoria do trabalhador e o número específico de vistos formais de trabalho relativos à função de "desossador" (deboning, meat bonner) para o período, por exemplo. Portanto, não basta ao trabalhador ter somente o desejo de ir atuar profissionalmente na Irlanda, este deve ser recrutado em função da necessidade do mercado local (IRELAND, 2019).

Nesse sentido, o fator trabalho está diretamente correlacionado ao fenômeno da migração, todavia, este processo está condicionado a outros aspectos, tal qual o interesse do próprio capital acerca da viabilidade deste processo, uma vez que na medida em que o capitalismo necessita de trabalhadores para que exista alguma produção em larga escala e, por conseguinte, produção de mais-valia, o trabalhador (sujeito social) está apto ao emprego em um determinado lugar, contudo, quando este cenário se modifica, este mesmo trabalhador pode ser descartado prontamente (MORAES; NASCIMENTO, 2013).

Adicionalmente, é importante indicar que os fluxos migratórios dão-se, justamente, devidos aos condicionantes econômicos e as desigualdades regionais em que o fator preponderante de expulsão ou de atração é o próprio trabalho (MORAES; NASCIMENTO, 2013). Assim sendo, cabe reproduzir novamente os argumentos de David Harvey (2018), em que este cita que os movimentos migratórios são, também, resultado das reestruturações espaciais do capital.

Desta feita, a migração tornou-se uma estratégia de sobrevivência aos trabalhadores frente à falta de oportunidades para o pleno emprego e o trabalho decente em seus países de origem, associadas à falta de segurança e de boas condições de vida neste local (FREITAS JÚNIOR; TORRES; BOUCINHAS FILHO, 2017). Contudo, esta situação é sempre contraditória, uma vez que há inúmeros obstáculos a serem enfrentados pelos migrantes e membros de suas famílias, desde o momento de saída, trajeto, chegada e, mesmo, no árduo processo de integração a nova sociedade, tanto do ponto de vista simbólico como pragmático (GONÇALVES; SOUZA, 2019, p. 12).

Por conseguinte e especificamente, a divulgação das vagas prossegue sendo realizada, majoritariamente, por meio das redes conformadas pelos próprios "desossadores". Estas são disponibilizadas por e-mail para os sindicatos da categoria no Brasil, que as repassam aos seus contatos; são direcionadas à grupos de WhatsApp específicos (por exemplo: "Desossadores do Brasil"), que as disponibilizam aos membros da lista e, a partir destes, outros trabalhadores da categoria são informados e mobilizados; também são propagandeadas em vídeos sobre o tema no YouTube em canais específicos (por exemplo: "Amigos do Frigorífico"); são direcionadas a grupos do Facebook sobre o tema (por exemplo: "Venha trabalhar na Irlanda: buscamos os melhores profissionais brasileiros com experiência comprovada em frigoríficos"); são postadas vagas no Instagram (por exemplo: \#desossadores) e, também, são direcionadas a atores-chave no Brasil. Normalmente um trabalhador "desossador" já com experiência e uma rede de contatos estabelecida que atua como sendo um facilitador do contato e contratação de mais trabalhadores com destino ao exterior.

Adicionalmente, a demanda e o perfil das vagas também são direcionados a empresas especializadas no recrutamento e seleção destes trabalhadores no Brasil. Cabe a estas empresas divulgar; receber os currículos, pré-avaliá-los; contatar os pré-selecionados; avaliar os vídeos do exercício profissional; avaliar os 
trabalhadores selecionados em lócus; realizar todos os procedimentos relativos à contratação; realizar os procedimentos relativos à obtenção do visto; viabilizar a logística necessária ao trânsito deste trabalhador do Brasil ao seu local de destino final. Este trabalho pode ser desenvolvido por um agente de ligação que desenvolve o mesmo serviço, por vezes até de modo informal. Ou, por fim, estes trâmites podem ser desenvoltos pela própria empresa contratante do exterior, por meio de seu departamento de recursos humanos ou representantes no Brasil.

Frente aos argumentos supracitados, cabe destacar que a oferta de vaga, a aderência ao processo seletivo e o aceite do trabalho no exterior é muito facilitado pela existência de "algum conhecido" no local de destino, esta pessoa/grupo pode ser um colega, parente, conterrâneo ou, mesmo, um patrício, não necessariamente é uma pessoa/grupo "conhecida" de fato, mas, a proximidade subjetiva e simbólica acaba por viabilizar o processo.

Nesse sentido, Massey (1987, p. 169) nos indica e reforça o argumento de que as redes sociais mais importantes se fundam em relações de parentesco, de amizade, de trabalho e na origem comum. Por conseguinte, essas relações não são criadas pelo processo migratório em si, mas, são adaptadas por ele e reforçadas pela experiência comum da migração.

Estas redes sociais interligadas mantém ativo um grande conjunto de expectativas complementares e sinérgicas em função de comportamento e atributos determinados, que buscam apoiar dinamicamente o movimento de pessoas, unindo migrantes e não migrantes, que se conectam a comunidades de origem e a lugares específicos do país de destino, conformando uma rede migratória fundamentada em uma rede social. Essas redes se tornam autossuficientes com o passar do tempo, em função do capital social que provê aos migrantes em potencial, os contatos pessoais com colegas, parentes, amigos e conterrâneos. Desta feita, oferecendo a estes oportunidades de emprego, acolhida e, mesmo, assistência financeira no destino (SOARES, 2002, p. 19).

Estas redes ainda exercem outras funções, tais como a transmissão de informações; o efeito multiplicador; manutenção das relações origem-destino, antes e depois da migração e, transformação do padrão migratório. Portanto, diante do impacto de momentos de crises político-econômicas conjunturais, há o impulso dos primeiros fluxos migratórios a um determinado país de destino. Isso porque na gênese dos fluxos migratórios existem sempre fatores específicos de expulsão ou atração. Mas, por conseguinte, os fluxos migratórios são influenciados diretamente pelas redes sociais, que contribuem não apenas para fornecer os referenciais do local de destino e a inserção do migrante no mercado de trabalho local, estas se configuram, sobretudo, como o esteio para manutenção deste sujeito no local escolhido (SALES, 1999, p. 34).

Neste sentido, cabe ainda destacar que as redes determinam a migração na medida em que estas estabelecem articulações com outras redes sociais organizadas com a função de efetivar a migração, em associação direta com fatores de ordem social, econômico, político, simbólico, afetivo, etc. Desta forma, o migrante potencial deve estar inserido na rede migratória internacional de modo adequado, se não, é pouco provável que a migração se dê efetivamente. Portanto, o perfil das conexões e laços da rede social da qual o sujeito faz parte, deve conferir a este o potencial para participar de uma rede migratória internacional para que consiga migrar (SOARES, 2002, p. 26).

Especificamente acerca da situação dos trabalhadores "desossadores" de carne bovina provenientes de Nova Andradina (MS) que trabalham na cidade de 
Clones, na Irlanda (ponto III), podemos fracionar este assunto em três segmentos a fim de abordar adequadamente as especificidades do tema em foco: a) perfil do grupo (objeto de estudo); b) descrição dos procedimentos relativos à migração; c) situação e perspectiva geral no local.

Para tanto, acerca do item (a) desta subdivisão, podemos indicar que o grupo estudado é composto por 6 (seis) homens, com idades entre 25 e 38 anos, com ensino médio completo. Destes 3 (três) são casados, todos possuem filhos. Suas esposas, companheiras, namoradas, filhos (as) e famílias permanecem no Brasil.

Cabe destacar que destes, três são nascidos em Nova Andradina (MS), dois são oriundos de cidades do interior do estado de São Paulo e, um do Maranhão.

A este grupo, como a tantos outros, podemos destacar que o trabalho é o componente necessário ao desenvolvimento econômico de uma localidade. E, ao trabalho são atribuídas inúmeras grandezas que o colocam como sendo um fator determinante na erradicação da pobreza, miséria e consolidação do crescimento econômico (RIBEIRO, 2017). Auxiliando a edificação de sentimentos relacionados uma autoestima equilibrada pelo senso de independência e de segurança, inclusive no que diz respeito à manutenção da própria família (NEVES et. all., 2018; KUBO; GOUVÊA, 2012).

Paralelamente, este grupo foi escolhido para a pesquisa, visto como foram juntos (mesma turma), selecionados e cumpriram lado a lado todo o processo de migração e, agora, de trabalho no exterior. Outro ponto em comum é que todos estavam atuando profissionalmente nos frigoríficos da cidade de Nova Andradina (MS), quando se deu início este processo.

Com relação a sua situação pretérita em Nova Andradina (MS), todos relataram estarem empregados. Deste grupo, absolutamente em todos os casos o oficio de "desossador" têm sido a principal ou, única ocupação laboral desde o início de suas carreiras profissionais. Neste grupo, todos se consideram como sendo o "arrimo de família", no que diz respeito às questões financeiras e da economia doméstica de suas famílias, mesmo que suas esposas, companheiras ou namoradas também possuam empregos e/ou renda própria.

Para exercer esta função laboral no Brasil, o trabalhador "desossador" recebe (em média) um salário de: $\mathrm{R} \$ 1.560,90$ (mil quinhentos e sessenta Reais e noventa centavos), para cumprir uma jornada de trabalho de 44 horas/semanais, quando contratado em regime formal, com carteira assinada (CLT). Esta categoria conta com piso salarial (para o ano de 2020) de $R \$ 1.442,83$ (cargo CBO 8485-15) (SALÁRIO, 2020).

No estado de Mato Grosso do Sul, a média de salários ao cargo é de $\mathrm{R} \$ 1.609,17$. Especificamente em Nova Andradina, a média salarial para o cargo de trabalhador "desossador" é de R\$1.665,94 (SALÁRIO, 2020).

Nesse sentido, é pertinente destacar que no período de 05/2019 até 12/2019 (no Brasil), houve 4.731 contratações deste tipo de profissional no Brasil, formais, com carteira assinada. Todavia, no mesmo período, houve 5.195 demissões, resultando em um saldo negativo de (-) 464 empregos gerados no mercado de trabalho para o cargo em específico, uma queda de (-) 33.27\% (SALÁRIO, 2020).

De modo geral, todos os entrevistados indicaram que, por meio de seus trabalhos e salários, levavam uma vida digna com suas famílias em Nova Andradina (MS). Deste grupo, por exemplo, 4 possuem casas próprias (ainda financiadas), todos possuem motocicletas próprias (quitadas e/ou financiadas) e, 2 ainda possuem carros próprios (quitados e/ou financiados). 
Mas, absolutamente todos os entrevistados relataram que fizeram a opção por migrar para trabalhar no exterior, em função dos salários recebidos em Euro $(€)$, a fim de melhorarem as condições relativas à qualidade de vida de suas famílias no Brasil.

O salário ofertado para os trabalhadores na Irlanda, na época de sua contratação era de $1.200,00 €$, o equivalente a $R \$ 5.892,00$, em valores convertidos diretamente, no ano de 2018, período da contratação destes trabalhadores. Ou seja, o soldo oferecido era, naquela ocasião, $354 \%$ maior, pelo mesmo trabalho. Em 2020, o salário ofertado é de 2.291,00€ (ABP, 2020a) e, este valor convertido diretamente renderia ao trabalhador "desossador" cerca de $\mathrm{R} \$ 12.944,00$ ao câmbio praticado em Março deste ano, portanto, um soldo com valor $777 \%$ maior que o oferecido em Nova Andradina (MS, Brasil), para o desenvolvimento da mesma função, inclusive, por um período de trabalho de 39 horas/semanais, portanto (-) $11 \%$, que a carga horária desta função no Brasil.

O valor do Euro com relação ao Real (taxa de câmbio) faz da Europa um destino cada vez mais atraente para os trabalhadores latino-americanos (CSEM, 2008). Evidentemente, este é um cenário extremamente simbólico e até leviano, uma vez que o custo de vida do trabalhador na Europa dá-se em Euro, tal qual seu salário e, o custo de vida naquele lugar é mais elevado se, comparado ao brasileiro (ZUCARE; CARVALHO; PANIZ, 2020). Contudo, este é um cálculo comum dentre os trabalhadores migrantes internacionais no momento da decisão de partida para o País de destino, fato que possibilita o exercício da remessa de recursos financeiros aos seus familiares no Brasil.

Esta situação dá-se, inclusive, fomentada fortemente pelas taxas de câmbio, historicamente, favoráveis a esta ação. Nesse sentido, passa haver a estes trabalhadores a possibilidade para formação de poupanças, investimentos e, sobretudo, incremento na qualidade de vida da família (com aportes destinados à saúde e educação, por exemplo) e, mesmo, de sua comunidade no Brasil, frente à injeção de recursos financeiros no comércio local (CEROVIC; BEATON, 2017).

Nesse contexto, Martes e Soares (2006), nos indicam que cerca de $80 \%$ dos emigrantes brasileiros remetem recursos financeiros ao Brasil com alguma regularidade. Dinheiro este que possui como finalidade: ajuda familiar $(76 \%)$, aquisição de imóveis no Brasil (25\%), aplicação em investimentos financeiros (16\%), pagamento de dívidas (6\%), ajuda a entidades (4\%). Essa distribuição reforça as evidências de que as remessas monetárias, raramente, são utilizadas como o propósito de investimento em produção, fato que remete a, histórica, inexistência de ambiente social, político e econômico propícios no Brasil a este direcionamento.

Adiante, com relação ao ponto (b) "descrição dos procedimentos relativos à migração", podemos descrever o processo que se deu para com este grupo analisado. Iniciou-se na medida da demanda de empresa frigorifica contratante $(A B P$ Food Group), na cidade de Clones, na Irlanda, a fim de instrumentalizar, conforme seus interesses, a ampliação de sua produção e processamento em função de seu mercado consumidor interno e, principalmente exterior (BEEF POINT, 2020).

Desta forma, um "desossador" brasileiro já contratado pela empresa, entrou em contato, via redes sociais, com seus contatos em Nova Andradina (MS) e, também, no interior do estado de São Paulo. Assim sendo, os trabalhadores "desossadores" interessados na oferta de vagas, encaminharam seus currículos, contatos e vídeos de suas atuações a este contato.

Em seguida, os pré-selecionados foram contatados, via telefone, por uma empresa brasileira de recrutamento e seleção que os entrevistou pessoalmente na 
cidade de Campo Grande, capital do estado de Mato Grosso do Sul. Posteriormente, os selecionados passaram por uma avaliação prática, realizada em Nova Andradina (MS), com a presença de representantes da empresa de recursos humanos e um técnico do frigorífico irlandês.

A posteriori, os aprovados e, definitivamente selecionados, forneceram seus dados pessoais para a empresa de recrutamento e seleção que, providenciou a contratação destes pela $A B P$ Food Group, seus vistos de trabalho para atuarem na Irlanda e os meios logísticos para que este grupo saísse de Nova Andradina (MS), passando por São Paulo (SP) e, Dublin para, por fim, chegarem ao seu destino final, na cidade de Clones, na Irlanda.

Frente ao cenário descrito podemos compreender que o recrutamento ativo de trabalhadores migrantes constitui o argumento central na explicação de migrações de trabalho. Desta forma, estas migrações com destinos à Países industrializados acontecem, unicamente, porque empregadores ou governos recrutam estes migrantes (PINHO, 2015).

Com relação à abordagem teórica acerca das redes existentes neste processo, podemos indicar que estas podem ser definidas como sendo o conjunto de unidades sociais e das relações pré-estabelecidas direta ou indiretamente entre elas, por meio de cadeias de comprimento variável. Neste sentido, ainda podemos destacar que estas redes aglutinam em si uma base de afeto e interesses comuns, em que um conjunto de pessoas (e, instituições), coordena suas ações a fim de atingir um objetivo específico. Ainda, podemos salientar que estas redes são complexas, frente às sobreposições de esferas institucionais nas relações existentes entre os participantes destas redes (ser um familiar ou colega de trabalho, por exemplo), ou mesmo, é possível mencionar que estas redes podem ser acionadas pelos indivíduos quando estes pretendem, mesmo sem que estes reconheçam a sua forma e, mesmo, sua existência efetiva (PINHO, 2015).

Com relação ao uso da internet, podemos indicar que esta funciona como sendo uma ferramenta facilitadora e preponderante para criação e manutenção de redes sociais entre migrantes transnacionais, uma vez que estas esteiam as relações afetivas e emocionais por meio da conexão online, bem como é o meio mais fácil e viável para que os migrantes obtenham informações acerca da burocracia relativa ao processo migratório, à obtenção de trabalhos, etc. (BARTH; COGO, 2009).

Por conseguinte, com relação ao ponto: (c) situação e perspectiva geral no local, é pertinente destacar que a cidade de Clones (Figura 02), no condado de Monaghan, na Irlanda desenvolveu-se a partir de um assentamento monástico com início no Século VI. Fica a acerca de 140 quilômetros de Dublin, capital do País. Esta pequena urbe possui uma população de 1,680 habitantes (CSO, 2016).

Neste município esta instalada uma das unidades de abate e processamento de carne bovina da ABP Food Group. Que é o maior grupo privado a atuar no segmento agroindustrial (frigorífico) da Europa, com unidades produtivas localizadas em diversos países do continente europeu (ABP, 2020b), com especial adensamento de suas atividades na Irlanda (seu País sede), Reino Unido e Polônia e atuação nos mercados da Europa, da América do Norte e do Sudeste Asiático (ABP, 2020c).

A iniciativa deste grupo esta condicionado ao próprio perfil produtivo da Irlanda, em que atividades relacionadas à agricultura e a pecuária estão sinergicamente atrelados à própria cultura e identidade do País, sendo que o setor é 
responsável diretamente pelo arranjo do uso e ocupação do território e, de parte importante da base socioeconômica desta nação (HANRAHAN, 2020).

O setor do agronegócio é responsável por $8 \%$ do PIB nacional, por $8,1 \%$ do total de empregos formais, por $9 \%$ das exportações. A área total do País é de 6.9 milhões de hectares e, destes 4.3 milhões hectares são destinados à agropecuária, sendo que $80 \%$ da área agricultável é composta pelo cultivo de pastagens para 0 gado. Sendo que $54 \%$ das iniciativas no meio rural estão vinculadas a criação de gado bovino, seja para o abate ou, para produção de leite e seus derivados (IFJ, 2007).

Figura 2. Mapa de Clones no âmbito de Irlanda e condado de Monaghan

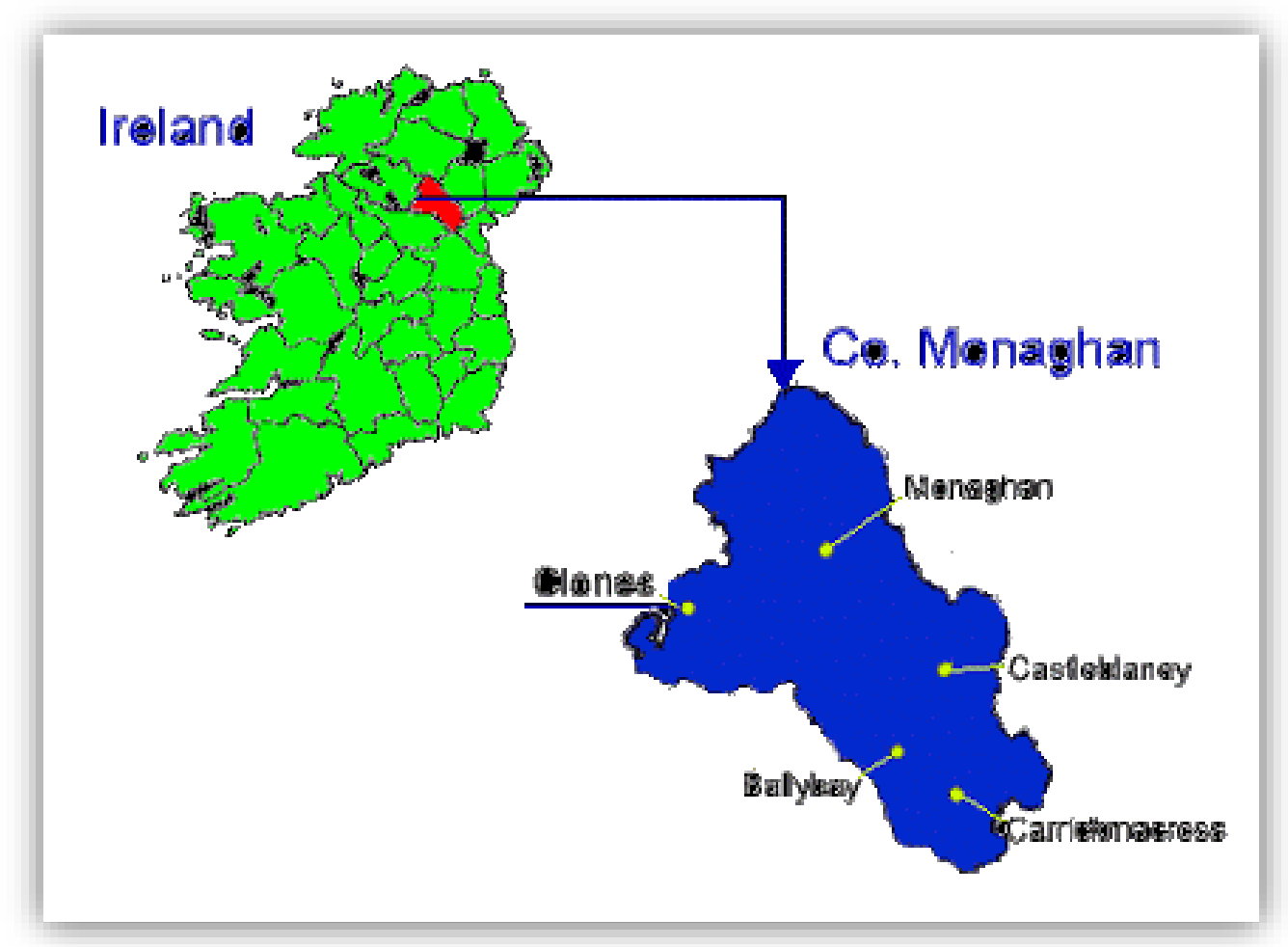

Fonte: Paragon, (2020)

Cabe destacar que o governo, em conjunto com as associações de produtores, de processadores e demais empresas privadas ligadas as cadeias produtivas do setor agroindustrial do país, desde 2016, desenvolvem e já aplicam um programa de incentivos financeiros e tecnológicos (públicos) para ampliação da produção e da qualidade dos produtos de origem animal da Irlanda, a fim de alcançar até 2025 um incremento do volume de produção de $20 \%$ (com relação ao patamar de 2015). (IFC, 2015; MII, 2016; IFA, 2016).

Contudo, o ano de 2018 foi um período extremamente delicado para o setor, uma vez que os preços praticados pela comercialização da arroba do boi estavam extremamente baixos, inviabilizando a atividade no País e, colocando em risco o planejamento estratégico do setor e das políticas públicas destinadas à ampliação e manutenção deste importante segmento socioeconômico da Irlanda. As preocupações com relação à sobretaxação dos produtos da Irlanda, em especial àqueles relacionados à agroindústria, em função do Brexit, por parte dos mercados associados à União Europeia (UE), deteriorou ainda mais as expectativas os produtores e das cadeias produtivas atreladas. Demandando ainda mais atenção e 
investimentos por parte do Estado, no que diz respeito à regulação do setor e dos subsídios destinados a sua sustentação (HANRAHAN, 2018).

Ainda nesse sentido, o ano de 2019 também não foi mais fácil ao setor no País, uma vez que dada a concentração (oligopólio) por parte dos processadores e varejistas, houve, por parte dos produtores, uma campanha intensiva e ofensiva em prol de melhores repasses e preços pagos a estes. Esta situação perdurou por pelo menos 6 meses, houveram bloqueios de acesso as plantas frigoríficas e, por conseguinte, retaliações por parte das empresas processadoras, com demissões em massa e lobby intenso junto ao governo (COYNE, 2019).

Neste sentido, podemos observar neste caso que na disputa entre produtores e processadores (ambos detentores de Capital), quem saiu prejudicado da contenda foram os trabalhadores (proletariado). Evidenciando, inequivocamente, a existência assimétrica e dinâmica da luta de classes na contemporaneidade deste cenário e, a forte precarização do valor do trabalho e do trabalhador enquanto sujeito social legítimo (e, ser humano digno). Assim sendo, podemos citar Clauss Offe, em que este autor afirma, ainda em 1989, que:

as formas contemporâneas de atividade social normalmente designadas como 'trabalho' não têm uma racionalidade comum nem características empíricas compartilhadas e, [...] nesse sentido o trabalho não é apenas objetivamente amorfo, mas também está se tornando subjetivamente periférico (OFFE, 1989, p. 194).

Estamos, portanto, diante de uma nova fase de desconstrução do trabalho sem precedentes em toda era moderna. Portanto, também vale citar Ricardo Antunes, em que este autor afirma, já em 2018, que:

Esta fenomenologia dos modos de ser desta precarização demonstra a ampliação acentuada de trabalhos submetidos a sucessivos contratos temporários, sem estabilidade, sem registro em carteira, etc., quando não na situação de desemprego (ANTUNES, 2018, p. 176).

Paralelamente, cabe destacar que o mercado frigorífico na Irlanda é bastante dinâmico, mas, conta com um arranjo produtivo que favorece majoritariamente as empresas processadoras. Três grandes grupos privados dominam o mercado local de compra e processamento de proteína animal, sendo que a ABP possui $27 \%$ deste arranjo, a Dawn Meat 22\%, a Kepak 11\% (totalizando: 60\%), edificando assimetrias econômicas, políticas e sociais neste segmento de mercado (PORCHERON, 2019).

Assim sendo, foram/estão inseridos neste cenário conflitante e repleto de disputas e incertezas políticas, econômicas e sociais o grupo de trabalhadores "desossadores" advindos de Nova Andradina (MS, Brasil), que está desde o mês de fevereiro de 2018 em Clones, na Irlanda.

Desta feita, com relação à chegada do grupo, a primeira impressão e o maior impacto fora a questão do clima local. Ao saírem do Brasil, desfrutavam do intenso calor do Verão e ao chegarem à Irlanda, se depararam com as baixas temperaturas do Inverno do hemisfério norte (CORRÊA, 2019). Nova Andradina, no Mato Grosso do Sul (Brasil), possui uma temperatura média anual de $22.7^{\circ} \mathrm{C}$, com valor de pluviosidade média anual de 136mm (CLIMATE DATA, 2020a). Já Clones, em Monaghan (Irlanda), possui uma temperatura média anual de $8.9^{\circ} \mathrm{C}$, com valor de 
pluviosidade média anual de 923mm (CLIMATE DATA, 2020b). Portanto, comparando estas especificidades, a temperatura em Clones é (-) $39 \%$, do que em Nova Andradina e, a média anual de pluviosidade de Clones é $67 \%$ maior que em Nova Andradina, configurando um clima totalmente exótico aos brasileiros.

Uma vez que estes trabalhadores chegaram a Clones em uma sexta-feira e iniciaram seus afazeres no frigorífico logo na segunda-feira próxima, este estresse climático inicial em função da exposição ao frio lhes seria capaz de perturbar o equilíbrio do organismo (homeostase) (SUSIN, 2015).

Neste grupo, somente um trabalhador citou não ter ficado doente (gripado/resfriado) neste período de adaptação, uma vez que já estaria fazendo uso contínuo de vitaminas, para melhorar o sistema imunológico. O que faz todo sentido biológico, uma vez que a ampliação da capacidade do sistema imunitário do corpo humano está diretamente correlacionada a uma ingestão adequada de alimentos (ou, suplementos alimentares) compostos por nutrientes específicos, dentre os quais as vitaminas e minerais, que favorecem diretamente as funções de defesa do organismo, melhorando a qualidade de vida dos indivíduos (BIASEBETTI; RODRIGUES; MAZUR, 2018; SARNI et. all., 2010).

Com relação à estadia, quatro trabalhadores estão compartilhando uma casa, alugada e cedida pela própria empresa como alojamento e, dois foram alocados em outra residência, juntos a diferentes trabalhadores migrantes oriundos de outros países da Europa (neste caso, da Polônia).

Parte do grupo que permaneceu junto, indicou que a casa oferece a infraestrutura adequada para a devida acomodação, cada sujeito possui um quarto para si e, todos dividem um mesmo banheiro, cozinha e sala de estar comuns. Neste caso específico, não houve a citação de qualquer inconveniente nas relações interpessoais dos moradores desta "república".

Contudo, os dois outros trabalhadores "desossadores" brasileiros que seguiram à outra morada, relataram um estranhamento muito evidente na convivência com os trabalhadores poloneses, implicando certo descontentamento no cotidiano comum desta "república" no que tange a esta situação.

A permanência nestes alojamentos (ou, "repúblicas") não é compulsória, mas, se o trabalhador decidir buscar outro local de residência deve arcar com a totalidade dos custos e da burocracia que esta decisão implica para si.

Cabe destacar que o cenário descrito pode ser compreendido como um fenômeno relativo ao choque cultural, que é uma desorientação psicológica causada por mal-entendido ou desentendimento causado pelas diferenças culturais entre sujeitos distintos. Ocorre devido à falta de conhecimento, experiência e/ou rigidez pessoal dos sujeitos envolvidos na relação. Assim é possível compreender que os valores pessoais intrínsecos (culturais) afloram como razões, não como causas deste choque cultural. Enquanto as causas são factuais, os valores são culturais e díspares (FRAGA, 1999).

Contudo, como o objetivo primário destes trabalhadores é otimizar o uso de seus salários a fim de estabelecer algum excedente para que as remessas aos seus familiares no Brasil se efetivem plenamente, mesmo estes dois últimos sujeitos, têm buscado superar a fase de crise inicial e, adotar uma postura de adaptação, em que se busca aprender os significados das novas culturas que vão se relacionar, a fim de desenvolver estratégias que Ihes permitam lidar melhor com as situações cotidianas e, com o tempo, se ajustar adequadamente ao novo cenário (BECKER; STERNBERG, 2016). Para que se dê este excedente de recursos oriundos dos salários, o estilo de vida destes trabalhadores é espartano. 
Um ponto importante a ser destacado é que, apesar da importância - efetiva e simbólica - das remessas de recursos feitas por estes trabalhadores aos seus no Brasil, a fim de garantir-lhes alguma ascensão social e econômica, as ausências deles, por vezes, trazem consigo implicações sociais, psicológicas e emocionais extremamente negativas e permanentes as suas esposas, companheiras, namoradas e filhos (as) (TRAPP; ANDRADE, 2017; SCARPELLINI; CARLOS, 2011; BENCZIK, 2011).

Com relação ao exercício laboral específico dentro do frigorífico, os trabalhadores brasileiros consultados não tiveram nenhuma dificuldade em executar seus afazeres, uma vez que a configuração, o layout da linha de produção e o trabalho propriamente dito, na Irlanda, se assemelham completamente àquele desenvolvido em Nova Andradina (MS, Brasil) (FURQUIM, 2017).

Outro ponto importante neste processo de adaptação dos trabalhadores, é que o responsável pelo grupo de trabalho composto pelos brasileiros (líder de linha), também é brasileiro, com experiência no trabalho e na empresa, que repassa todas as orientações em língua portuguesas e, quando necessário, faz a tradução do inglês aos novos componentes do grupo. Nesse sentido, este ato de traduzir, mesmo que de modo espontâneo e despretensioso por parte deste sujeito, perfaz a ponte entre duas culturas, sendo assim, toda tradução parte de um conjunto de sentidos expressos em palavras de um determinado idioma que deve ser transposto integralmente em um novo idioma, que também possui suas características culturais e sociais próprias (OLIVEIRA, 2017).

Inclusive, uma das condições para a contratação dos brasileiros por parte da $A B P$ Food Group é que estes trabalhadores migrantes frequentem, ao menos uma vez por semana, aulas de Inglês. Para que possam obter autonomia em seus diálogos, incrementar seu desempenho nas atividades laborais e, também, inserir-se adequadamente a nova realidade social e cultural de Clones, na Irlanda.

Com relação ao cotidiano destes trabalhadores, estes nos indicaram, em sua totalidade que, em princípio, estão vivendo em função do trabalho e do estudo (da língua inglesa). Outras atividades, relacionadas a novos trabalhos e ao lazer, foram sendo introduzidas paulatinamente no dia-a-dia deste grupo. A priori, nos indicaram que a questão do clima frio, foi um fator importante ao resguardo destes trabalhadores, mas, com o fim do inverno rigoroso e, a aproximação do período de férias na Europa (junho e julho), 3 dos 6 trabalhadores deste grupo conseguiram, para além de seus trabalhos fixos no frigorífico, ocupações temporárias em bares (pubs) e restaurantes locais, atuando como garçons e auxiliares de cozinha. Desta forma, incrementando sua renda neste período.

Contudo, é uníssona a exclamação dos brasileiros ao citar que os irlandeses têm sido receptivos e polidos. Contudo, há um distanciamento efetivo por parte destes locais com qualquer estrangeiro inserido na comunidade. Se for turista é sempre bem-vindo, mas, se for para morar e trabalhar há certo incomodo dissimulado na socialização.

Um exemplo banal desta situação é que os rapazes solteiros têm se relacionado, majoritariamente, com mulheres que também são migrantes. No caso deste grupo em específico, não estavam com brasileiras. A descrição deste panorama nos leva a compreender que mesmo que os membros deste grupo não tenham sido vítimas de nenhum ato de xenofobia (discriminação, violência, etc.). A edificação das relações de trabalho e amizades, majoritariamente, restritas a brasileiros e outros estrangeiros, os coloca em uma condição de composição de 
gueto. Assim sendo, sua inserção plena a sociedade e a cultura irlandesa, são mais expectativas idealizadas, do que fato consumado.

Neste sentido, para além da abordagem relativa à segmentação sócioespacial intrínseca ao fato, o gueto passa a ser uma conformação arbitrária de identidade coletiva dos migrantes internacionais - efetivada por parte dos locais. Todavia, cabe destacar que esta concepção e narrativa é extremamente complexa, uma vez que, ao mesmo tempo em que auxilia na elaboração de argumentos que reafirmam o conjunto (heterogêneo) de trabalhadores migrantes residentes como sendo conformado por indivíduos singulares, exóticos ou, até mesmo, aberrantes, alimentando crenças nacionalistas e preconceituosas já existentes no lugar, mas, contraditoriamente, permite uma maior integração multicultural e multi-étnica que ascende um sentimento de orgulho coletivo por parte deste grupo (WACQUANT, 2004).

Adiante, é importante destacar que o elo destes trabalhadores com sua família e amigos no Brasil têm se dado de modo muito intenso por meio do uso da internet nos celulares, especificamente, utilizando-se do aplicativo WhatsApp, tanto nas mensagens digitadas, quanto pelo envio e recebimento de fotos e vídeos compartilhados diuturnamente à sua rede social. Inclusive a rede social (virtual) mais utilizada por este grupo é o Facebook. Inclusive, o uso e acesso a estas redes sociais acaba por consumir um tempo de lazer importante destes sujeitos.

Outro ponto comum aos migrantes internacionais, aos brasileiros nesta condição e, aos membros deste grupo em específico é a saudade. Tanto do Brasil (apesar das motivações para migração), quanto, especialmente, de suas famílias e amigos. Acerca deste cenário, é pertinente indicar que questões emocionais dolorosas permeiam a existência dos indivíduos nesta condição. Desta feita, sentimentos de luto, tristeza, saudades em relação ao que foi deixado para trás (amigos, parentes, gastronomia, a terra em que nasceram, etc.) (FRANKEN; COUTINHO; RAMOS, 2009).

Destarte, as condições objetivas ainda não lhes favoreçam ao pronto retorno ao Brasil (e, Nova Andradina, especificamente), o desejo de retornar mantém-se vivo como um sinal da esperança, de dias melhores, de estar próximo a parentes, vizinhos e amigos que estão fisicamente distantes. O desejo de retornar é um alimento para suas almas. Deste modo, estes trabalhadores migrantes internacionais experimentam o drama do ausente que está presente e do presente que está ausente (MENEZES, 2012).

Aos membros deste grupo, a expectativa do retorno ao Brasil, por enquanto, deve se dar somente no próximo período de férias. Portanto, com a intenção de regressar as atividades laborais e a nova vida na Irlanda. A motivação central da viagem é sempre rever os familiares e entes queridos (matar as saudades), verificar como estão sendo empregados os recursos enviados pelos trabalhadores migrantes na manutenção de suas famílias (saúde, educação, etc.), conferir como estão seus investimentos em Nova Andradina (neste caso) e, além disso, deleitar-se com a sensação de "vitória" (e, status) junto aos seus.

Desta forma, edificam ao seu circulo familiar, de amigos e colegas de ofício uma narrativa bastante positiva com relação à situação de trabalho e qualidade de vida fora do Brasil, negligenciando ou omitindo fatos negativos desta jornada e, inserindo no imaginário coletivo a fantasia do cenário externo e, por conseguinte, cativando novos trabalhadores a compor a dinâmica desta rede e, por fim, ingressar a este fluxo migratório. 


\section{CONSIDERAÇÕES FINAIS}

Ao alcançarmos este derradeiro ponto do texto, compreendemos que é possível e pertinente afirmarmos que, frente ao objetivo proposto inicialmente e aos procedimentos, métodos e técnicas utilizados ao longo desta pesquisa, conseguimos estabelecer um cenário descritivo, permeado por dados científicos, argumentações e discussões teóricas inerente e acerca da situação dos trabalhadores "desossadores" de carne bovina procedentes de Nova Andradina, no Mato Grosso do Sul, que atuam na Europa, especificamente na Irlanda, cidade de Clones, no condado de Monaghan.

Este panorama dá-se em um contexto dramático de redução do trabalho vivo e aumento do desemprego em âmbito global, bem como das ocupações sem contrato de trabalho, informais, flexíveis, temporárias e precárias, provocando uma maior mobilidade dos trabalhadores entre setores de produção e locais de trabalho. Neste cenário, o trabalhador se dispõe a deixar sua família, casa, amigos, cidade/País natal para vender sua força de trabalho onde houver demanda. Tornando-se totalmente disponível a exploração do mercado de trabalho. E, há um agravante ainda, visto como não encontra um lugar seguro pra se fixar, desloca-se com mais frequência, exigindo desprendimento e adaptabilidade, ou seja, capacidade de submeter-se ao novo (de novo). Exigindo deste trabalhador uma complexa subjetividade flexível, do ponto de vista físico, cognitivo, comportamental e ético. Sendo capaz de desprender-se dos lugares e das pessoas, bem como de projetos de vida e meios de sobrevivência. Vive um constante recomeçar. Recomeçar este que não significa a construção de uma nova forma de vida, por vezes, até de uma perspectiva de futuro (VENDRAMINI, 2018).

Ainda, com relação ao sujeito migrante, antes de tudo ele é um sujeito da classe trabalhadora que busca reproduzir-se enquanto tal, em formas cada vez mais precárias, inseguras e vulneráveis. Vivem em zonas periféricas, muitas vezes guetos, sujeito ao preconceito e discriminação, bem como à violência, É um sujeito com família, sexo, raça, etnia, idade e escolaridade. Enfim, constitui uma massa de trabalhadores completamente disponível para a exploração, tendo que se mover entre diferentes ocupações e regiões (do mundo) (VENDRAMINI, 2018).

Por fim, é plausível assegurar que não é fácil se estabelecer em um ambiente estranho, diferente do que the é familiar, na condição de ser estrangeiro/migrante. Se, muitas vezes, é difícil de chegar ao País de destino, permanecer neste novo País também é um processo permeado de desafios. Ou seja, não são apenas os obstáculos concretos (as barreiras físicas), que se colocam diante dos trabalhadores migrantes. Há barreiras linguísticas, de costumes e de leis locais, de diferenças culturais, diversos entraves como o alcance da documentação migratória, acesso ao sistema bancário, etc., o período de adaptação e reconhecimento territorial do novo lugar, até a saudade da vida que deixou e das pessoas que permaneceram no seu País de origem são fatores que perfazem este árduo processo. Portanto, não são poucos os obstáculos enfrentados pelos trabalhadores que decidem migrar (WALDMAN, 2018). 


\section{REFERÊNCIAS BIBLIOGRÁFICAS}

ABP FOOD GROUP. Aplications: Job: Meat Boner. 2020a. Disponível em: https://abpfoodgroup.com/careers/current-vacancies/ (Acessado em 28.03.2020, às 22h24min).

. Award winning beef. Ardee: ABP, 2020b.

. Our business. 2020c. Disponível em: https://abpfoodgroup.com/ourbusiness/ (Acessado em 28.03.2020, às 22h49min).

ACNUR - ALTO COMISSARIADO DAS NAÇÕES UNIDAS PARA REFUGIADOS. Migrações, refúgio e apatridia: guia para comunicadores. Brasília: ACNUR. IDH. AVINA. MIGRAMUNDO. FICAS, 2019.

ANTUNES, R.. O privilégio da servidão: o novo proletariado e serviços na era digital. São Paulo: Boitempo, 2018.

AOUN, S.; VERDI, A. R. Inserção do Grupo JBS na dinâmica do capitalismo contemporâneo. Rev. de Economia Agrícola. v. 57. n. 2. 2010.

BARTH, D. L.; COGO, D. Redes sociais e usos da internet por migrantes brasileiros na Espanha. In.: ANAIS XXXII Congresso Brasileiro de Ciências da Comunicação. Curitiba: INTERCOM, 2009.

BEEFPOINT. JBS inicia abates em Nova Andradina/MS. 2012. Disponível em: https://www.beefpoint.com.br/jbs-inicia-abates-em-nova-andradina-ms/ (Acessado em 23.10.2019 às 20h15min).

Frigorífico irlandês ABP amplia oferta de carne no varejo on-line da China. 2018. Disponível em: https://www.beefpoint.com.br/frigorifico-irlandes-abp-ampliaoferta-de-carne-no-varejo-on-line-da-china/ (Acessado em 04.03.2020 às 21h59min).

BECKER, L. C.; STERNBERG, R. Choque cultural: um processo na vida de todo migrante. Brasília: MRE, 2016.

BENCZIK, E. B. P. A importância da figura paterna para o desenvolvimento infantil. Rev. Psicopedagogia. n. 28. 2011.

BRASIL. A divisão de Mato Grosso. Brasília: Presidência da República, 1977.

CBO 8485-15: Desossador. 2019. Disponível em: http://www.mtecbo.gov.br/cbosite/pages/pesquisas/BuscaPorTituloResultado.jsf (Acessado em 22.10.2019).

CASTRO NETO, J. L.; YOSHITAKE, M. FRAGA, M. S.; GUIMARÃES, S. P. Custos das remessas internacionais de recursos: o caso de migrantes brasileiros. Rev. Patrimônio: Lazer e Turismo. v. 7. n. 11. 2010. 
CEROVIC, S.; BEATON, K. Migração e remessas na América Latina e Caribe: fuga de cérebros e estabilização econômica. Nova York: FMI, 2017.

CORRÊA, A. Estações do ano na Europa: veja como são e compare com o Brasil. Disponível em: https://www.eurodicas.com.br/estacoes-do-ano-na-europa/ (Acessado em 01.04.2020 às 22h19min).

CORRÊA, V. B.; CORRÊA, L. S. Charqueadas: uma alternativa na economia pecuária do sul de Mato Grosso (1880-193/40). Rev. Albuquerque (História). v. 2. n. 3. 2010.

COYNE, A. redundancies ate Irish meat firms: Kepak and ABP ongoing beef dispute. 2019. Disponível em: https://www.just-food.com/news/redundancies-at-irish-meatfirms-kepak-and-abp-as-ongoing-beef-dispute-bites id142244.aspx (Acessado em: 29.03.2020 às 23h28min).

CSEM - CENTRO SCALABRIANO DE ESTUDOS MIGRATÓRIOS. Migrações e desenvolvimento: qual o papel das remessas? n. 71. 2008.

CSO - CENTRAL STATISTICS OFFICE (IRELAND). Population: Census 2016: Clones. $2016 . \quad$ Disponível em: https://www.citypopulation.de/en/ireland/towns/monaghan/0292 clones/ (Acessado em 28.03.2020 às 21h54min).

CLIMATE DATA. Clima Nova Andradina (Brasil). 2020a. Disponível em: https://pt.climate-data.org/america-do-sul/brasil/mato-grosso-do-sul/nova-andradina43511/ (Acessado em 01.04.2020 às 22h15min).

. Clima Monaghan (Irlanda). 2020b Disponível em: https://pt.climatedata.org/europa/irlanda/monaghan/monaghan-11695/ (Acessado em 01.04.2020 às 22h15min).

DUTRA, C. A. S. O território Ofaié e o conceito de poder e violência em Mato Grosso do Sul. Rev. História Unisinos. n. 15. 2011.

Ofaié: o povo do mel. Campo Grande: CIMI, 1991.

FACHIN, O. Fundamentos de metodologia. São Paulo: Saraiva, 2006.

FARIA, G.; ZAMBERLAN, C. O. DIAS, E. P.; CASTAGNA. Expansão da fronteira agrícola: impacto das políticas de desenvolvimento regional no Centro-Oeste brasileiro. In: Anais do 48ํㅡㄹ Congresso da SOBER. Campo Grande: SOBER, 2010.

FLICK, U. Introdução à pesquisa qualitativa. Porto Alegre: Artmed, 2009.

FOOD INGREDIENTS BRASIL. Grupo JBS: o maior em carne bovina. n. 6. 2009.

FRAGA, V. F. Choque cultural como aprendizado profissional e humano. Rev. RAP. v. 33. n. 5. 1999. 
FRANKEN, I.; COUTINHO, M. P. L.; RAMOS, N. Migração e qualidade de vida: um estudo psicossocial com brasileiros migrantes. Rev. Estudos de Psicologia. n. 26. 2009.

FREITAS JÚNIOR, A. R.; TORRES, D. B.; BOUCINHAS FILHO, J. C. Migração, trabalho e direitos humanos. São Paulo: LTR, 2017.

FURQUIM, N. R. Tecnologia e o serviço de rastreabilidade na cadeia produtiva de carne bovina no Brasil. Rev. Espacios. v. 38. n. 19. 2017.

GOES FILHO, S. S. Navegantes, Bandeirantes, Diplomatas: um ensaio sobre a formação das fronteiras do Brasil. Brasília: FUNAG, 2015.

GOLANI, L.; MOITA, R. O oligopsônio dos frigoríficos: uma análise empírica de poder de mercado. Insper Working Paper. n. 228. 2010.

GONÇALVES, A. H.; JOHNSON, G. A. Fronteiras e migrações internacionais: pensando criticamente as contradições da situação europeia contemporânea (um estudo de caso). In: Anais da XV Semana de Pós-graduação em Ciências Sociais da UNESP/FCLAR. UNESP: Araraquara, 2016.

.; Reflexões críticas sobre o acesso a condição de cidadania ao migrante internacional: um quadro geral e contemporâneo. In: Anais da IX Jornada Científica da Pós-graduação em Geografia da UFRJ. UFRJ: Rio de Janeiro, 2016.

.; JESUS, A. D. Persona non Grata: reflexões sobre fronteiras e migração internacional. In: Anais do Congresso Internacional de Direitos Humanos da UCDB e UFMS. UCDB/UFMS: Campo Grande, 2016.

.; GONÇALVES, M. A. Córrego Manolo Umbaracá em Nova Andradina (MS): degradação ambiental e urbanização. In: Anais do II Simpósio de Estudos Urbanos: SEURB. UEP: Marechal Candido Rondon, 2013.

v. 20. N. 03. 2019.

.; SOUZA, R. V. B. Migração e trabalho: a situação do Brasil. Rev. Pegada.

GONÇALVES, F.; CARVALHO, A. G. B. M. A realidade indígena em Mato Grosso do Sul: o caso dos Ofaié em Brasilândia/MS. In: Anais do II Simpósio Internacional de Geografia Agrária. Presidente Prudente: UNESP PP, 2005.

HANRAHAN, K. The significance of beef. Dublin: AFDA, 2020.

. Transpaency in beefmarkets in Ireland. Brussels: TEAGASC, 2018.

HARVEY, D. A loucura da razão econômica: Marx e o capital no século XXI. São Paulo: Boitempo, 2018.

IBGE - INSTITUTO BRASILEIRO DE GEOGRAFIA E ESTATÍSTICA. IBGE Cidades: Mato Grosso do Sul: Nova Andradina. Disponível em: 
https://cidades.ibge.gov.br/brasil/ms/nova-andradina/panorama (Acessado em 18.10.2019 às 20h27min).

IRELAND. Critical skills occupations list. 2019. Disponível em: https://dbei.gov.ie/en/What-We-Do/Workplace-and-Skills/EmploymentPermits/Employment-Permit-Eligibility/Highly-Skilled-Eligible-Occupations-List/ (Acessado em 06.11.2019 às 15h25min).

IFA - IRISH FARMERS ASSOCIATION. Proposed transaction in the Irish meat processing sector. Dublin: IFA, 2016.

IFC - IRISH FARM CENTRE. Future of the beef sector in Ireland. Dublin: IFC. ICCS, 2015.

IFJ - IRISH FARMERS JOURNAL. Cattle Breeding in Ireland. Dublin: IFJ, 2007.

JBS. Relatório anual e de sustentabilidade: 2018. São Paulo: Aproach Comunicação, 2018.

JESUS, A. D; GONÇALVES, A. H. Quando o estranho bate à porta: reflexões sobre migrações e fronteiras. Rev. Eletrônica da AGB/TL. n. 26. 2017.

KUBO, S. H.; GOUVÊA, M. A. Análise de fatores associados ao significado do trabalho. Rev. R.Adm. v. 47. N. 4. 2012.

MARTES, A. C. B.; SOARES, W. Remessas de recursos dos imigrantes. Rev. Estudos Avançados. n. 20. 2006.

MASSEY, Douglas S. et al. Return to Aztlan: the social process of international migration from Western Mexico. Los Angeles: University of California Press, 1987.

MATIAS, G. S. Migrações e cidadania. Lisboa: FFMS, 2014.

MENEZES, M. A. Migrações e mobilidades: repensando teorias, tipologias e conceitos. In.: TEIXEIRA, P. E.; BRAGA, A. M. C.; BAENINGER, R. (org.) Migrações: implicações passadas, presentes e futuras. Marília: Oficina Universitária; São Paulo: Cultura Acadêmica, 2012.

MII - MEAT INDUSTRY IRELAND. Irish beef sector delivering growth. Dublin: MII, 2016.

MONTEIRO, H. F. A concentração da indústria de frigoríficos e a crise da pecuária na região sudeste do Pará: uma abordagem multiacetada. Belém: UFPA, 2012. (Mestrado em Altos Estudos Amazônicos).

MORAES, S. B.; NASCIMENTO, E. C. A relação migração-trabalho: uma análise sob a ótica da questão social. In: Anais do IV Seminário CETROS. Fortaleza, 2013. 
MOREIRA, F. G.; SCHLINDWEIN, M. M. Sucessão da gestão na agricultura familiar: um estudo de caso no assentamento Santa Olga no município de Nova Andradina em Mato Grosso do Sul. Rev. NERA. n. 29. 2015.

MOTA, C. G. História de um silêncio: a guerra contra o Paraguai (1864-1870) 130 anos depois. Rev. Estudos Avançados. n. 9. 1995.

NANTES, M. A. A saga da família Nantes. Campo Grande: Ed. Oeste, 2007.

NEVES, D. R.; NASCIMENTO, R. P.; FELIX JR., M. S.; SILVA, F. A.; ANDRADE, R. O. B. Sentido e significado do trabalho: uma análise dos artigos publicados em periódicos associados à Scientific Periodical Eletronic Library. Rev. Cad. EBAPE.BR. v. 16. № 02. Rio de Janeiro: FGV, 2018.

OFFE, C. Capitalismo desorganizado. São Paulo: Brasiliense, 1989.

OLIVEIRA, C. L. A importância da tradução: reflexões sobre o papel do tradutor. Rev. Communitas. v. 1. n. 1. 2017.

ORTELN, C. B. Internacionalização das empresas brasileiras processadoras de carnes: transpondo barreiras. São Paulo: USP, 2016. (Mestrado em Administração).

PARAGON. Map location: Clones Ireland. 2020. Disponível em: http://homepage.eircom.net/ paragonbar/location.html (Acessado em 30.03.2020 às 00h03min).

PELLICCIARI NETTO, G. Nova Andradina: 45 anos (álbum biográfico, didático e histórico): Nova Andradina: Jornal O Independente, 2004.

PINHO, F. Redes sociais no recrutamento de imigrantes: fundamentos teóricos de uma proposta de explicação. Rev. Sociologia (Univ. do Porto). v. 29. 2015.

PNUD - PROGRAMA DAS NAÇÕES UNIDAS PARA O DESENVOLVIMENTO. Atlas do Desenvolvimento Humano no Brasil: Nova Andradina (MS). 2019. Disponível em: http://www.atlasbrasil.org.br/2013/pt/perfil m/nova-andradina ms (Acessado em 18.10.2019 às 20h29min).

PORCHERON, E. A look back at 3 years of concentration in the red meat sector in the UK and Ireland. Paris: UNIGRAINS, 2019.

QUEIROZ, P. R. C. Revisitando um velho modelo: contribuições para um debate ainda atual sobre história econômica de Mato Grosso/Mato Grosso do Sul. Rev. Intermeio (UFMS). v. 14. 2008.

REVISTA HOJE. Grupo Independência: 30 anos. n 21. Ano 03. Nova Andradina, 2002.

RIBEIRO, R. C. A influência e a importância do trabalho para a sociedade e suas diferentes concepções. In.: ANAIS. VIII Jornada Internacional de Políticas Públicas. São Luís: UFMA, 2017. 
SALÁRIO. Desossador - Salário 2020 e Mercado de Trabalho. 2020. Disponível em: https://www.salario.com.br/profissao/desossador-cbo-848515/ $\quad$ (Acessado em 03.03.2020 às 22h37min).

SALES, Teresa. Brasileiros longe de casa. São Paulo: Cortez, 1999.

SANTOS, C. A. A formação social e territorial de Nova Andradina: o papel da igreja e a política de colonização (1958-972). Nova Andradina: UFMS, 2010.

SAQUET, M. A.; MONDARDO, M. L. A construção de territórios na migração por meio de redes de relações sociais. Rev. NERA. № 13. 2008.

SARNI, R. O. S.; SOUZA, F. I. S.; COCCO, R. R.; MALLOZI, M. C.; SOLÉ, D. Micronutrientes e sistema imunológico. Rev. Bras. Alerg. Imunopatol. v. 33. n. 1 2010.

SCARPELLINI, M.; CARLOS, V. Y. Monoparentalidade feminina e vulnerabilidade social: a realidade de mulheres chefes de família no município de Apucarana (PR, Brasil). ANAIS. II Simpósio Gênero e Políticas Públicas. Londrina: UEL, 2011.

SEMAC - SECRETARIA DE ESTADO DE MEIO AMBIENTE, PLANEJAMENTO, CIÊNCIA E TECNOLOGIA. Mapa: Aptidão agrícola das terras do Mato Grosso do Sul. Campo Grande: SEMAC, 2013a.

Mapa: Susceptibilidade à erosão nas terras o Mato Grosso do Sul. Campo Grande: SEMAC, 2013b.

Mapa: Vegetação nas terras do Mato Grosso do Sul. Campo Grande: SEMAC, 2013c.

SILVA, R. P. Imigrantes goianas na Irlanda: agência e interpretações. Rev. Latinoamericana de Geografia e Gênero. v. 07. n. 02. 2016.

SOARES, W. Da metáfora à substância: redes sociais, redes migratórias e migração nacional e internacional em Valadares e Ipatinga. Belo Horizonte: UFMG, 2002. (Doutorado em Demografia).

SUSIN, R. C. Exposição ocupacional em ambientes frios: avaliação e aplicação da metodologia do IREQ. Pato Branco: UTFPR, 2015.

TOSIN, G. Subsídios para estudos sobre transcriação de poesia em ambientes digitais. Rev. Texto Digital. v. 7. n. 2. Florianópolis, 2011.

TRAPP, E. H. H.; ANDRADE, R. S. As consequências da ausência paterna na vida emocional dos filhos. Rev. Ciência Contemporânea. v. 2. n. 1. 2017.

VENDRAMINI, C. R. A categoria migração na perspectiva do materialismo histórico e dialético. Rev. Katál. v. 21 n. 2. 2018. 
WACQUANT, L. Que é gueto? Construindo um conceito sociológico. Rev. Soc. Polít. n. 23. 2004.

WALDMAN, T. C. Uma introdução às migrações internacionais no Brasil contemporâneo. Brasília: OIM Brasil, 2018.

ZOTI, J C. História e identidade da região Sul de Mato Grosso: a ocupação e colonização da região de Nova Andradina (1933-1950). Rev. Bilros. v. 5. n. 8. 2017.

ZUCARE, C.; CARVALHO, C.; PANIZ, J. Como morar na Irlanda: confira tudo sobre viver no país. 2020. Disponível em: https://www.eurodicas.com.br/como-morar-nairlanda/ (Acessado em 26.03.2020 às 23h20min). 